Scientific Journal Warsaw University of Life Sciences - SGGW

Problems of World Agriculture volume 17 (XXXII), number 4, 2017: 120-129

DOI: $10.22630 /$ PRS.2017.17.4.88

\author{
Joanna Jaroszewska ${ }^{1}$ \\ Institute of Agricultural and Food Economics - National Research Institute \\ Robert Pietrzykowski ${ }^{2}$ \\ Warsaw University of Life Sciences - SGGW

\section{Convergence of the Labour Productivity in European Union Agriculture}

\begin{abstract}
The objective of the paper is to examine the changes in the level of diversification of the labour productivity in the European Union countries in the years 1998-2015, and then to determine whether there is any convergence of the labour productivity among these countries. The labour productivity has been calculated as a relation of the gross value added at constant prices per one fulltime employee. The study used the Economic Accounts for Agriculture (EAA) and the Agricultural Labour Input (ALI). The study covered the European Union countries, broken down by the countries of the „old" EU (EU-15) and the countries admitted to the EU after 2004. In order to determine the changes occurring in these countries, sigma-convergence $(\sigma)$ and beta-convergence $(\beta)$ have been used. The study shows that after 2011 there was a process of convergence among the EU countries in terms of the labour productivity in agriculture.
\end{abstract}

Key words: labour productivity, convergence, UE

JEL Classification: C01, J21, R10, Q10

\title{
Introduction
}

All European Union countries (EU-28) are subject to the same common agricultural policy, however, agriculture in these countries varies significantly, both structurally and socially. This is affected by many factors, the most common are historical events i.e. the fact that the countries were subject to various legal and political systems, e.g. Communism, the level of economic development, as well as different natural and climate conditions, diversified agricultural intensity and different national agricultural policy (Baer-Nawrocka, 2010). This diversification of agriculture puts the weaker countries in an adverse situation while undermining their competitive capacity. This paper analyses - in the perspective of its transformation - the labour productivity, which is considered to be one of the important factors of economic growth and a basic determinant of the competitive capacity (Gołaś, Kozera, 2008; Mrówczyńska-Kamińska, 2013; Misala, Ślusarczyk, 1999; Poczta, 2003; Latruffe, 2010; European Commission, 2008; OECD, 2011). The low productivity of production factors, including labour, determines the difficult economic and income situation of farms (Gołaś, Kozera, 2008). Important was also to examine whether among the individual countries there is a process of reducing the level of the labour productivity in the agricultural sector, or just the opposite - this diversification grows. This is essential due

\footnotetext{
${ }^{1}$ MSc. Eng., Department of General Economics IAFE-NRI, ul. Świętokrzyska 20, 00-002 Warszawa, e-mail: joanna.jaroszewska@ierigz.waw.pl, https://orcid.org/0000-0003-3733-4082

${ }^{2} \mathrm{PhD}$, Department of Agricultural Economics and International Economic Relations, Faculty of Economic Sciences WULS - SGGW, ul. Nowoursynowska 166,02-787 Warszawa, e-mail: robert_pietrzykowski@sggw.pl, https://orcid.org/0000-0002-6122-3043
} 
to the implementation of the EU cohesion policy, whose task is to reduce disparities between the regions and to prevent the backwardness of disadvantaged regions. The main objective of the paper is to determine the changes in the EU countries due to the labour productivity in the agricultural sector. The specific objective is to assess the disparities among the countries of the old Union and those newly admitted after 2004. As the study hypothesis, the paper adopted the statement that in the analysed period (1998-2015) the level of the labour productivity in the agricultural sector is being aligned (betaconvergence).

\section{Data}

The study uses two EU statistics, namely, the Economic Accounts for Agriculture (EAA) and the Agricultural Labour Input (ALI) ${ }^{3}$. The Economic Accounts for Agriculture are macroeconomic accounts, which means that they apply to the entire agricultural sector. They are drawn up according to a unified methodology ${ }^{4}$ developed by EUROSTAT, which makes it possible to make comparisons of the economic situation in agriculture among the Community countries. This analysis uses the gross value added ${ }^{5}$ from the EAA at constant prices in million EUR, generated in agriculture of the individual European countries. This value has been reduced by subsidies to the agricultural production. The labour inputs in agriculture $^{6}$ have been taken from ALI and expressed in thousands AWU ${ }^{7}$.The analysis covers the years 1998-2015, taking into account the availability of individual country data.

\section{Methodology}

In order to examine the labour productivity in the EU countries, the transformations in the labour productivity have been analysed in the context of their direction and growth rate of the changes in the level of the gross value added and agricultural labour inputs. From among the EU-28 countries, the countries of the old EU and the countries newly admitted after 2004 have been singled out $^{8}$. The analysed feature was the economic labour productivity expressed as a ratio of the sum of produced products to incurred labour inputs (FTS) (Encyklopedia..., 1984). On the other hand, in order to determine the changes in the

\footnotetext{
${ }^{3}$ Labour input statistics is also available on the EUROSTAT website, in the tab of Economic Accounts for Agriculture (http://ec.europa.eu/eurostat/data/database).

4 Methodology of the Economic Accounts for Agriculture is available on the EUROSTAT website: http://ec.europa.eu/eurostat/cache/metadata/en/aact_esms.htm

${ }^{5}$ Gross value added is the value of production of the agricultural sector less the value of direct consumption (mineral fertilisers, plant protection products, feedstuffs, energy, fuel, seed material, veterinary services, agricultural services etc.).

${ }^{6}$ Agricultural labour inputs mean paid labour (labour of permanent and odd hired workers) and unpaid labour (labour of family members and neighbours' help).

${ }^{7}$ Annual work unit (AWU) means an Full-time equivalent. It is calculated by dividing the number of hours worked annually by the annual number of hours corresponding to an Full-time equivalent. In Poland, the labour unit of 2,120 hours of work a year, i.e. 265 workdays, 8 hours each, has been applied. When calculating the labour inputs expressed in AWU (in accordance with the Eurostat methodology), a requirement was followed that there is no more than 1 AWU per 1 person, even if in fact this person works longer.

${ }^{8}$ Bulgaria, Romania joined the EU in 2007, Croatia in 2013, other countries in 2004.
} 
European Union countries in terms of the labour productivity, sigma-convergence $(\sigma)$ and beta-covergenence $(\beta)$ have been used. Convergence is referred to as the development/imitation of the poorer countries in relation to the richer countries. In the analysed case, the countries of the old EU are perceived as the rich, developed countries, while the countries which joined the EU after 2004 are identified as the countries with the worse economic situation. In case of sigma-convergence, it is determined how the change occurs due to the labour productivity over the analysed period of time. To measure $\sigma$ convergence, we may use the standard deviation, coefficient of variation or Williamson and Theil coefficients (Cuadrado-Roura and Parellada 2002, Łaźniewska et al., 2011). This paper uses the classic approach to estimate sigma-convergence in a form of the standard deviation of the performance level of natural logarithms of the labour productivity level $\mathrm{y}_{\mathrm{it}}$ to average values in the period $t(t=1,2, \ldots, T)$ according to the formula:

$$
\sigma=\sqrt{\frac{\sum_{i=1}^{N}\left(\ln y_{i t}-\ln \bar{y}_{t}\right)^{2}}{N}} d \operatorname{lat} t=1, \ldots, T
$$

where:

$\mathrm{N}$ number of analysed objects (countries) during the period t;

$y_{i t}$ labour productivity level in agriculture of the European countries during the period t;

$\bar{y}_{t}$ average labour productivity level in agriculture of the European countries during the period t.

To analyse beta-convergence, the $\beta$ factor obtained according to the following formula is most often applied:

$$
\ln \left(\frac{y_{i t}}{y_{i 0}}\right)=\alpha+\beta \ln \left(y_{i 0}\right)+\varepsilon_{i}
$$

where:

$y_{i 0}$ baseline labour productivity level in agriculture of the European countries during the period $\mathrm{t}=0$;

$\alpha \quad$ absolute term

$\beta$ coefficient of convergence;

$\varepsilon_{i} \quad$ random error with normal distribution $\mathrm{N}\left(0, \sigma^{2}\right)$.

In order to estimate the $\beta$ coefficient, the classic method of least squares for linear regression has been used. If we obtain the negative value of the $\beta$ coefficient of convergence, then we may talk about the occurrence of convergence of this type. It is necessary to check the relevance of the analysed coefficient i.e. to determine if it is different than zero. The paper estimated the value of the $\beta$ coefficient by using the confidence interval according to the formula:

$$
\begin{gathered}
\beta \in\left(\hat{\beta}-t_{(n-2)}^{\alpha} S_{\beta}, \hat{\beta}+t_{(n-2)}^{\alpha} S_{\beta}\right) \\
S_{\beta}=\sqrt{\frac{S^{2}}{\sum_{i=1}^{N}\left(\ln y_{i t}-\ln \bar{y}_{t}\right)^{2}}}
\end{gathered}
$$

where: 
$\hat{\beta} \quad$ estimator of the coefficient of convergence;

$t_{(n-2)}^{\alpha} \quad \alpha$-quantile of Student's t-distribution with (n-2) degrees of freedom;

$S_{\beta} \quad$ standard deviation for $\hat{\beta}$;

$S^{2} \quad$ residual variance for the regression function determined by formula 2 .

\section{Results}

The use of production factors in agriculture determines its competitiveness both at the international and global level. Of particular importance in this respect is the efficient use of labour resources. The existing disparities in the labour productivity are a major problem in the economic development of the countries. They also lead to the disturbance of their competitiveness and put the disadvantaged regions in an adverse situation (Baer-Nawrocka, Markiewicz, 2012). The applied division of the countries into the countries of the old EU (EU-15) and the countries admitted to the EU after 2004 allowed to extract the main trends in the labour productivity taking place in these groups of countries. In general, for all the analysed countries, taking into account their different dates of accession to the EU between the years 1998-2015, there has been a $93.5 \%$ increase in the labour productivity in agriculture (6.6 million to EUR 12.9/1 FTE) (Table 1).

Table 1. Average labour productivity, gross value added at constant prices $(2005=100)$, Total labour force input in thous. AWU in the years 1998-2015

\begin{tabular}{|c|c|c|c|c|c|c|c|c|c|c|c|c|c|c|c|c|c|c|c|}
\hline & 1998 & 1999 & 2000 & 2001 & 2002 & 2003 & 2004 & 2005 & 2006 & 2007 & 2008 & 2009 & 2010 & 2011 & 2012 & 2013 & 2014 & 2015 & \begin{tabular}{|c|} 
Average \\
annual rate of \\
change $(\%)$ \\
\end{tabular} \\
\hline \multicolumn{20}{|c|}{ Labour productivity (gross value added in mln euro/ total labour force input in thous. AWU) without subsidies on production } \\
\hline EU-15 & 13,29 & 14,82 & 15,32 & 15,35 & 16,24 & 16,11 & 18,23 & 18,11 & 18,10 & 18,55 & 19,94 & 20,66 & 19,24 & 20,23 & 19,63 & 19,95 & 22,60 & 24,37 & 0,03 \\
\hline $\begin{array}{l}\text { countries admitted to } \\
\text { the EU after 2004** }\end{array}$ & 2,10 & 2,23 & 2,39 & 2,53 & 3,17 & 3,24 & 3,85 & 3,91 & 3,84 & 3,70 & 4,70 & 4,94 & 4,48 & 4,95 & 4,59 & 5,27 & 5,91 & 6,16 & 0,06 \\
\hline Avarage & 6,65 & 7,29 & 6,97 & 7,16 & 7,86 & 7,90 & 9,13 & 8,89 & 8,81 & 8,78 & 10,19 & 10,64 & 9,78 & 10,52 & 10,00 & 10,76 & 12,13 & 12,87 & 0,04 \\
\hline \multicolumn{20}{|c|}{ Gross value added in mln euro, constant price $(2005=100)$, without subsidies on production } \\
\hline EU-15 & 3052,18 & 3294,75 & 3310,91 & \begin{tabular}{|l|}
3247,79 \\
\end{tabular} & 3361,64 & 3288,66 & 3640,29 & 3513,01 & 3439,97 & 3428,16 & 3591,36 & 3599,52 & 3345,70 & 3447,20 & 3330,73 & 3324,29 & 3746,45 & 4010,23 & 0,02 \\
\hline $\begin{array}{l}\text { countries admitted to } \\
\text { the EU after } 2004^{*}\end{array}$ & 766,25 & 773,41 & 550,77 & 555,69 & 577,77 & 556,49 & 624,24 & 638,46 & 600,51 & 542,12 & 666,36 & 679,25 & 565,71 & 616,16 & 567,55 & 644,90 & 709,20 & 714,39 & 0,00 \\
\hline Avarage & 1755,96 & 1845,26 & 1774,59 & 1761,48 & 1536,89 & 1493,15 & 1662,60 & 1591,68 & 1529,72 & 1456,08 & 1642,90 & 1659,60 & 1465,92 & 1549,83 & 1464,61 & 1552,50 & 1729,86 & 1800,16 & 0,00 \\
\hline \multicolumn{20}{|c|}{ Total labour force input in thous. AWU } \\
\hline EU-15 & 229,69 & 222,28 & 216,17 & 211,64 & \begin{tabular}{|l|}
207,04 \\
\end{tabular} & \begin{tabular}{|l|}
204,08 \\
\end{tabular} & 199,64 & \begin{tabular}{|l|}
193,94 \\
\end{tabular} & \begin{tabular}{|l|}
190,03 \\
\end{tabular} & \begin{tabular}{|l|l|}
184,79 \\
\end{tabular} & \begin{tabular}{|l|l|}
180,15 \\
\end{tabular} & 174,20 & \begin{tabular}{|l|l}
173,87 \\
\end{tabular} & \begin{tabular}{|l|}
170,44 \\
\end{tabular} & 169,67 & \begin{tabular}{|l|l|}
166,60 \\
\end{tabular} & 165,75 & 164,57 & $-0,02$ \\
\hline $\begin{array}{l}\text { countries admitted to } \\
\text { the EU after } 2004^{*}\end{array}$ & 226,74 & 177,45 & 195,17 & 185,88 & 182,23 & 171,56 & 162,32 & 163,17 & 156,29 & 146,43 & 141,78 & 137,44 & 126,35 & 124,59 & 123,63 & 122,28 & 119,99 & 115,96 & $-0,04$ \\
\hline Avarage & 228,50 & 202,08 & 206,57 & 199,78 & 195,62 & 188,92 & 182,10 & 178,99 & 173,55 & 165,87 & 161,19 & 156,04 & 149,92 & 147,36 & 146,48 & 144,32 & 142,67 & 139,88 & $-0,03$ \\
\hline
\end{tabular}

Source: own elaboration based on Economic Accounts for Agriculture (EAA) and the Agricultural Labour Input (Economic accounts for agriculture - values at constant prices $(2005=100)$ [aact eaa03] without subsidies for production and Agricultural Labour Input Statistics: absolute figures (1 000 annual work units) [aact_ali01]). EUROSTAT. Access: 2017-04-25. For groups of states, geometric averages have been calculated. 
It resulted only from a reduction in employment $(-0.03 \%)$, as the average annual rate of change in the gross value added has not changed in the analysed years. In case of the „old" EU, an increase in the labour productivity amounted to $83.4 \%$ and, for all newly admitted countries an increase by almost $200 \%$ was recorded. It is worth noting that all groups of the countries recorded an increase in the labour productivity, however, the strongest growth rate was characteristic of the newly admitted countries $(0.06 \%)$. In case of this group, an increase in the labour productivity was determined by an annual average decrease in employment by $-0.04 \%$, while the average annual gross value added has remained unchanged. The countries of the old EU were characterised by the lower growth rate of the labour productivity of $0.03 \%$, but they have gained it thanks to an increase in the value added by $0.02 \%$ and a simultaneous reduction in the labour inputs by $-0.02 \%$. This means that the newly admitted countries acquire their possibilities of increasing the labour productivity mainly from a decline in employment in agriculture. In contrast, the developed countries improve their labour productivity also by generating economic surplus from agriculture. On the other hand, the average level of the labour productivity in the EU-15 countries for the entire analysed period remained at a much higher level than the average for all new countries. It should be noted that in 2015 the newly admitted countries were characterised by the labour productivity which was by nearly four times lower than that of the countries of the old EU (the difference in case of Poland was more than sevenfold). However, seventeen years before, in 1998, the same relation was more than sixfold, and for Poland more than eightfold. Therefore, it may be assumed that, in the analysed period betaconvergence has taken place among the European countries. The following map shows the changes in the labour productivity in the analysed countries. Despite the general upward trends in the labour productivity in the analysed groups of the countries, the situation at the level of the individual countries was diverse. Two countries from the group of the countries which joined the EU after 2004, Malta and Croatia showed an annual average decline in the labour productivity. On the other hand, the highest upward trend in the labour productivity was demonstrated by Lithuania $(0.11 \%)$, Latvia $(0.10 \%)$ and Estonia $(0.09 \%)$. Poland demonstrated an annual average increase in the labour productivity of $0.04 \%$. Poland is characterised by one of the lowest labour productivities (EUR 3.3 million/AWU), the lower labour productivity in 2015 was characteristic only of Croatia (EUR 3.2 million/AWU). The main causes of this situation in Poland include large and poorly qualified labour resources, low degree of land concentration and low equipment with capital assets, which in consequence led to the low productivity of production factors (Gołaś, Kozera, 2008). A consequence of this state of affairs, noticeable by the farming population is its low income. In contrast, a solution to this issue is seen in a reduction or complete elimination of the social role of employment in farms, in particular, in small farms (Kołodziejczak, 2016) through employment in non-agricultural sectors. 


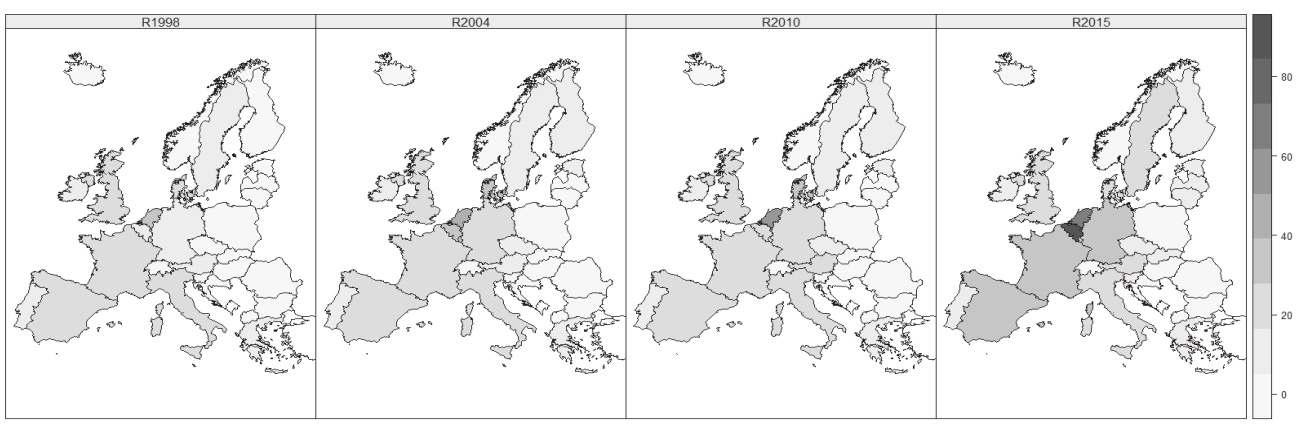

Fig. 1. Labour productivity level in agriculture for the EU-15 countries and for the countries admitted to the European Union in 2004, in the selected years

Source: own elaboration based on Economic Accounts for Agriculture (EAA): Economic accounts for agriculture values at constant prices $(2005=100)$ [aact_eaa03] without subsidies for production and Agricultural Labour Input Statistics: absolute figures (1 000 annual work units) [aact_ali01] Access: 25.04.2017.

The strong differentiation of the labour productivity is a consequence of the strong differentiation in the level of the gross value added in the analysed groups of the countries. In 2015, the average gross value added at constant prices and without production subsidies was almost sixfold among the groups of the countries (the difference amounted to EUR 3,295.84 million) for the benefit of the EU-15. However, in the year 1998 this difference was lower, nearly fourfold. This means that in terms of generating economic surplus, the newly admitted countries do not improved their situation but, on the contrary, they deteriorated it. In several countries, we may observe even a deterioration of results i.e. of an annual average decline in economic surplus. This problem applied to Malta $(0.03 \%)$, Slovakia $(-0.02 \%)$ and Croatia $(0.03 \%)$. Also among the EU-15 countries, we may see the same problem, namely in Denmark $(-0.02 \%)$ and Greece $(0.01 \%)$. A different trend occurred in case of such countries as Lithuania $(0.07 \%)$, Latvia $(0.05 \%)$, Poland and Estonia $(0.02 \%)$. Among the EU-15 countries, the strongest upward trend was identified in Belgium $(0.09 \%)$, Finland $(0.06 \%)$ and Sweden $(0.04 \%)$. Despite the relatively small average annual change in the gross value added, Poland with EUR 6,351.5 million in 2015 was characterised by the highest added value in agriculture in its group and significantly exceeded the average for both groups of the European countries. This value was comparable to the gross value added of agriculture in Great Britain (EUR 6,776.9 million). On the background of the significant diversification in the level of the labour productivity and gross value added between the groups of the countries, the level of labour inputs is comparable between these groups of the countries. This is illustrated in Fig. 2. The level of labour inputs of 230 thousand AWU was comparable at the beginning of the study period and was systematically decreasing in both analysed groups of the countries. The number of FTEs in agriculture of the EU-15 decreased by 65 thousand AWU, and in the newly admitted countries by 110.8 thousand AWU. Despite lower average employment in agriculture in the group of the newly admitted countries, this group includes the countries with the highest employment in agriculture, i.e. Poland with employment of 1,937.1 thousand AWU and Romania with 1,193.0 thousand AWU. Among the EU-15 countries, comparably high employment only applies to Italian agriculture only $(1,142.6$ thousand AWU). 


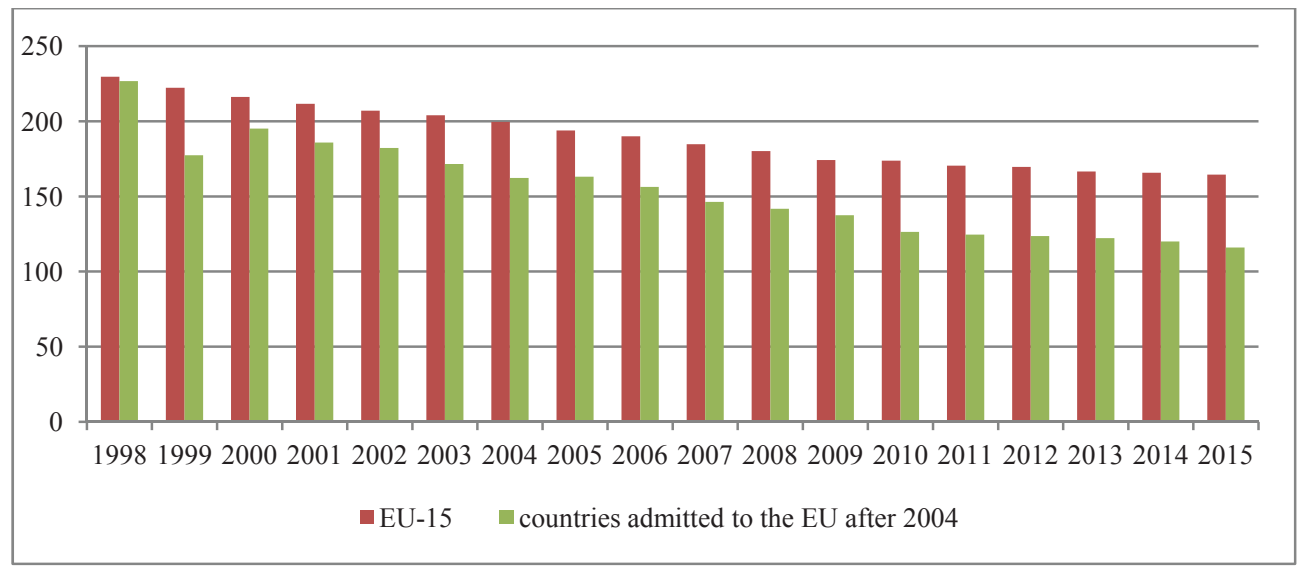

Fig. 2. Average total labour force input in agriculture of the EU-15 countries and newly admitted countries after 2004 (in thousand AWU).

Source: own elaboration based on EUROSTAT data. Agricultural Labour Input Statistics: absolute figures (1 000 annual work units) [aact_ali01] Accessed: 25 April 2017.

In the further part of this paper, we estimated sigma-convergence of the labour productivity in agriculture for the European countries in 2005, 2007, 2010 and 2015. Fig. 3 shows the evolution of the value for sigma-convergence for the EU countries calculated in accordance with formula 1 . The way of the evolution of the value in the chart allows to identify two periods: from 2004 to 2009 and from 2009 to 2015. In the first identified period, we cannot talk about reducing the value of the standard deviation for the labour productivity in agriculture. However, after 2009 we may talk about the decreasing values of sigma-convergence which would suggest its occurrence in this period and would suggest the presence of beta-convergence (cf. Łaźniewska et al., 2011). For the analysed countries this means that in the first years there were spatial inequalities among the countries as regards the analysed labour productivity, then after 2009 this differentiation among the countries started decreasing. This resulted in the improved relationship of the labour productivity between the Western countries and the Central and Eastern European countries.

Fig. 4 shows the values of beta-convergence for the labour productivity in agriculture of the European Union countries in the years 2004-2015. On the vertical axis, the values of the estimated $\beta$ coefficient have been marked. The baseline year is 2004 and then the $\beta$ coefficients have been estimated for the individual years. For each coefficient, the confidence intervals have been calculated in accordance with formula 3. A horizontal line, intersecting the vertical axis, marks the value of zero. We assume that if the confidence interval for the $\beta$ coefficient in the given year contains zero, we cannot determine the relevance of this coefficient, and thus beta-convergence. According to this reasoning, it should be noted that until 2010, we cannot talk about the presence of convergence for the labour productivity in agriculture. Only since 2011 a change has occurred and all obtained values of the $\beta$ coefficients for the individual years are negative, and therefore, we can conclude the presence of real convergence for the labour productivity in agriculture of the European Union countries. 


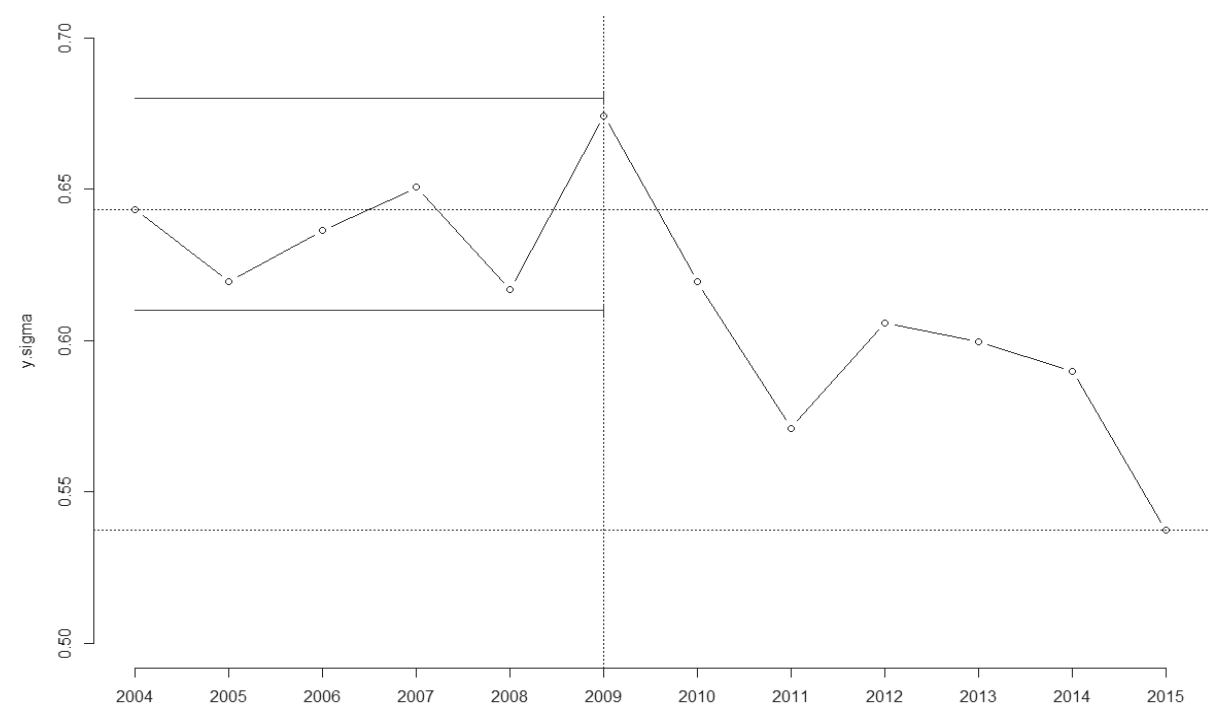

Fig. 3. Values of sigma-convergence for the labour productivity in agriculture of the European Union countries in the years 2004-2015.

Source: own elaboration based on Economic Accounts for Agriculture (EAA): Economic accounts for agriculture values at constant prices $(2005=100)$ [aact_eaa03] without subsidies for production and Agricultural Labour Input Statistics: absolute figures (1 000 annual work units) [aact_ali01] Accessed: 25 April 2017.

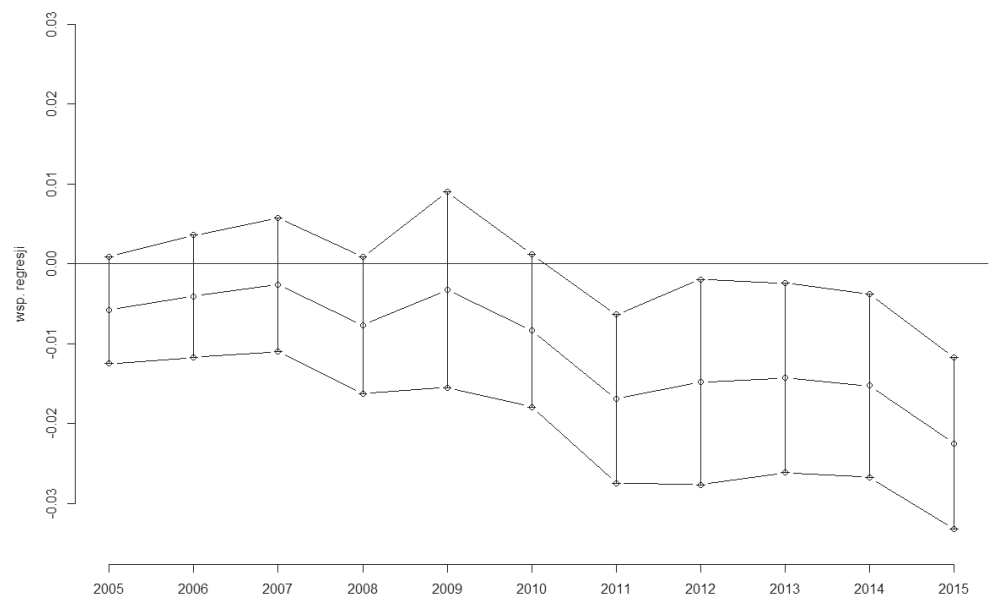

Fig. 4. Values of beta-convergence for the labour productivity in agriculture of the European countries in the years 2005-2015

Source: own elaboration based on Economic Accounts for Agriculture (EAA): Economic accounts for agriculture values at constant prices $(2005=100)$ [aact_eaa03] without subsidies for production and Agricultural Labour Input Statistics: absolute figures (1 000 annual work units) [aact ali01] Accessed: 25 April 2017. 


\section{Conclusions}

The analysis of changes in the labour productivity in terms of the direction and growth rate of changes in the level of the value added and labour inputs showed that in the European countries in the years 1998-2015 there were beneficial changes as regards the labour effectiveness. The distance between the countries of the old EU and newly admitted countries after 2004 was decreasing. However, the growth rate of this process was different. The countries which joined the EU after 2004 improved their productivity faster than the countries of the old EU, and they also reduced faster the labour inputs involved in agriculture. On the other hand, the increase in the labour productivity in their case was obtained only due to a reduction in the labour inputs. The average value added in their case has not improved in the analysed years. In turn, the EU-15 countries also increased the labour productivity due to the value added growth. It was noticed that in some countries the growth rate of changes in the analysed variables differed significantly from the averages for the identified groups of the countries. This was the case of Poland, Romania, Italy (the issue of labour inputs much above the average), Belgium, the Netherlands (the issue of the labour productivity much above the average for the EU-15 group). Both the level and growth rate of the studied phenomenon of the labour productivity, economic surplus and labour inputs involved in agriculture showed that both groups of the countries are decreasing the distance in terms of the labour productivity only, while increasing the distance in terms of the generated gross value added and labour inputs. However, it should be stressed that the gross value added used to calculate the labour productivity has been deprived of direct payments and presented in constant prices. Summing up the conducted study, we conclude that between the groups of the countries there are disparities both in terms of the labour productivity and the generated gross value added. The analysis of convergence allowed us to assess the presence of spatial inequalities among the countries when it comes to the labour productivity. The presence of beta-convergence indicates that the analysed two groups of the countries decrease the distance in terms of the labour productivity itself, which confirmed the hypothesis on aligning the level of the labour productivity in the agricultural sector, but only after 2011. But it has also been shown that the countries are increasing the distance in terms of the generated gross value added and labour inputs.

\section{References}

Baer-Nawrocka, A. (2010). Zasoby pracy jako przesłanka konkurencyjności rolnictwa nowych krajów członkowskich Unii Europejskiej. Roczniki Naukowe SERiA, 10(1), 16-22.

Baer-Nawrocka, A., Markiewicz, N. (2012). Procesy konwergencji/dywergencji w zakresie wydajności pracy w rolnictwie Unii Europejskiej - analiza regionalna, JARD, 3(25), 13-23.

Cuadrado-Roura, J.R., Parellada, M. (2002). Regional Convergence in the European Union, Springer-Verlag Berlin Heidelberg.

Encyklopedia Ekonomiczno-rolnicza. (1984). PWRiL, Warszawa.

European Commission (2009). European Competitiveness Report 2008, Luxembourg, Office for Official Publications of the European Communities.

Gołaś, Z., Kozera, M. (2008). Strategie wydajności pracy w gospodarstwach rolnych. JARD, 1(7), 73-87.

Kołodziejczak, W. (2016), Nadwyżka zatrudnienia w polskim rolnictwie-projekcja na tle państw Unii Europejskiej. ZN SGGW Problemy Rolnictwa Światowego, 16(1), 129-141. 
Latruffe, L. (2010). Competitiveness, Productivity and Efficiency in the Agricultural and Agri-Food Sectors, OECD Food, Agriculture and Fisheries Working Papers, No. 30, OECD Publishing. Accessed from: http://dx.doi.org/10.1787/5km91nkdt6d6-en.

Łaźniewska, E., Górecki, T., Chmielewski, R. (2011). Konwergencja regionalna, Wydawnictwo Uniwersytetu Ekonomicznego w Poznaniu, Poznań.

Misala, J., Ślusarczyk, B. (1999). Ocena międzynarodowej konkurencyjności czynnikowej Polski w okresie transformacji w świetle wyników badań empirycznych, [in:] Handel zagraniczny - metody, problemy, tendencje, eds. K. Budzowski, S. Wydymus, Materiały VII Ogólnopolskiej Konferencji Naukowej, Kraków, 67-86.

Mrówczyńska-Kamińska, A. (2013). Wydajność pracy w gospodarce żywnościowej w krajach Unii Europejskiej. Roczniki Naukowe SERiA, 15(4), 285-291.

OECD (2011). Fostering Productivity and Competitiveness in Agriculture, OECD Publishing. Accessed from: http://dx.doi.org/10.1787/9789264166820-en.

Poczta, W. (2003). Rolnictwo polskie w przededniu integracji z Unią Europejska, Wyd. AR, Poznań. 